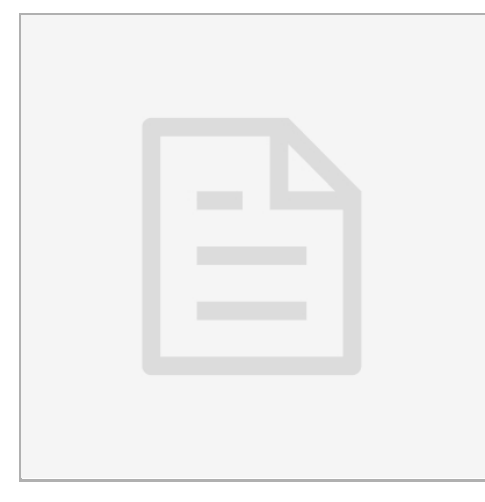

\section{DOI:}

dx.doi.org/10.17504/protocol s.io.4cqgsvw

Protocol Citation: Benjamin Izar, Parin Shah, Mei-Ju Su, Isaac Wakiro, Sara Napolitano, Jingyi Wu, Sébastien Vigneau, Asaf Rotem, Orit RozenblattRosen, Bruce Johnson, Aviv Regev . BRIDGEHTAPP Depletion of CD45+ cells frōm ovarian cancer ascites single cell suspensions for single-cell RNA-Seq. protocols.io

https://dx.doi.org/10.17504/p rotocols.io.4cqgsvw

License: This is an open access protocol distributed under the terms of the Creative Commons Attribution License, which permits unrestricted use, distribution, and reproduction in any medium, provided the original author and source are credited

Created: Jun 18, 2019

Last Modified: Jun 21, 2019

PROTOCOL integer ID: 24688

\section{(2) BRIDGE- HTAPP_Depletion of CD45 + cells from ovarian cancer ascites single cell suspensions for single-cell RNA- Seq ::}

Benjamin $\operatorname{Izar}^{1,2}$, Parin Shah ${ }^{1,2}$, Mei-Ju Su ${ }^{1,2}$, Isaac Wakiro ${ }^{1}$, Sara Napolitano ${ }^{3}$, Jingyi $\mathrm{Wu}^{1,2}$, Sébastien Vigneau ${ }^{1}$, Asaf Rotem $^{1,2}$, Orit Rozenblatt-Rosen 4,2, Bruce Johnson 1,2, Aviv Regev 4,5,6,7

\section{${ }^{1}$ Dana-Farber Cancer Institute; ${ }^{2}$ Human Tumor Atlas Pilot Project; ${ }^{3}$ University of California, Santa Barbara; ${ }^{4}$ Broad Institute; \\ ${ }^{5}$ Human Tumor Atlas Project; ${ }^{6}$ Massachusetts Institute of Technology; \\ ${ }^{7}$ Howard Hughes Medical Institute}<smiles>C1CCCCCC1</smiles>
Judit Jane-Valbuena The Broad Institute

\section{ABSTRACT}

This protocol is adapted from the CD45 MicroBeads MACS Separation protocol from Miltenyi Biotec (Cat No 130-045-801). CD45+ cells are labeled with microbeads following which, on passing through a MACS column in a magnetic field, they are retained within the column while the CD45- cells flow through and are collected for single-cell RNA-seq.

\section{GUIDELINES}

- Keep sample on ice and use cold reagents unless noted otherwise.

- Report information as indicated in the protocol.

\section{MATERIALS}

\section{MATERIALS}

88 LS Columns Miltenyi Biotec Catalog \#130-042-401

88 PBS pH 7.4 Thermo Fisher Scientific Catalog \#10010049

\& ULTRAPURE 0.5M EDTA pH 8.0 Thermo Fisher Scientific Catalog
\#15575020

88 ANTI-HUMAN CD45 MICROBEADS Miltenyi Biotec Catalog \#130-045-801

88 BSA Cell Signaling Technology Catalog \#9998S

88 MIDIMACS SEPARATOR Miltenyi Biotec Catalog \#130-042-302

88 MACS MULTISTAND Miltenyi Biotec Catalog \#130-042-303

\title{
SAFETY WARNINGS
}

(4) Follow general lab safety and institutional guidelines when working with sharps and human derived samples. 
Note

\section{DISCLAIMER}

You have been granted access to an HTAPP protocol posted in the HTAPP_LBRNCI or HTAN DCC protocols.io groups.

You hereby acknowledge that as a condition of having been provided with access to these protocols prior to their publication, you are required to comply with below guidelines:

The protocols in these groups are pre-publication and are not yet ready to be shared outside HTAN. They will eventually be made open access (per HTAPP project requirements), but until then, you agree that you will not disseminate beyond your lab or publish them without written approval of the protocol developers.

If you have questions or feedback about them, please contact Ellen at egelfand@broadinstitute.org. Many thanks for your interest!

- Set centrifuge to $4^{\circ} \mathrm{C}$.

- Prepare MACS buffer (PBS with 0.5\% BSA, 2 mM EDTA), degas, and keep on ice or store at $4^{\circ} \mathrm{C}$ for up to a few weeks.

- Label $15 \mathrm{~mL}$ conical tube as "CD45 negative fraction".

\section{Quality Control}

$1 \quad$ Mix $5 \mu \mathrm{L}$ of single-cell suspension with $5 \mu \mathrm{L}$ Trypan blue and load on hemocytometer.

2 Count and record the number of viable single-cells, dead single-cells, cell doublets, and whether debris are present. Take picture if possible.

\begin{tabular}{||l|l|}
\hline & $\begin{array}{l}\text { Qualit } \\
\text { y } \\
\text { Contr } \\
\text { ol }\end{array}$ \\
\hline $\begin{array}{l}\text { Numb } \\
\text { er of } \\
\text { Viable } \\
\text { Single } \\
\text { Cells } \\
\text { Count } \\
\text { ed }\end{array}$ \\
\hline
\end{tabular}




\begin{tabular}{|l|}
\hline Numb \\
er of \\
Dead \\
Single \\
Cells \\
Count \\
ed \\
\hline Numb \\
er of \\
Cell \\
Clum \\
ps or \\
Doubl \\
ets \\
Count \\
ed \\
\hline Conc \\
entrat \\
ion of \\
Viable \\
Single \\
Cells \\
(cells/ \\
HL) \\
\hline Conc \\
\hline entrat \\
ion of \\
Dead \\
Single \\
Cells \\
(cells/ \\
$\mu L$ ) \\
\hline Conc \\
entrat \\
ion of \\
Cell \\
Clum \\
ps or \\
Doubl \\
ets \\
(doubl \\
ets/ $\mu$ \\
L) \\
\hline Volu \\
me of \\
Single \\
Cell \\
Suspe \\
nsion \\
( $\mu \mathrm{L})$ \\
\hline Total \\
Numb \\
er of \\
Viable \\
Single \\
Cells \\
\hline Propo \\
rtion \\
of \\
Single \\
Cells \\
that \\
are \\
Viable \\
(\%)
\end{tabular}




\begin{tabular}{|l|l|}
\hline Propo \\
rtion \\
of Cell \\
Clum \\
ps or \\
Doubl \\
ets \\
(\%) \\
\hline Descri \\
\hline ption \\
of \\
debris \\
(if \\
any) \\
\hline
\end{tabular}

Note

Insert Picture:

\section{Magnetic Labeling}

3 Centrifuge at $580 \mathrm{~g}$ for 5 minutes in $4^{\circ} \mathrm{C}$ pre-cooled centrifuge.

00:05:00 Centrifugation

$8^{\circ} 4^{\circ} \mathrm{C}$ Wet lce

4 Remove supernatant as completely as possible without disrupting the pellet.

$8^{\circ} 4^{\circ} \mathrm{C}$ Wet lce

5 If cell number is lower than 10 million, resuspend cell pellet in $80 \mu \mathrm{L}$ MACS buffer. If cell number is higher than 10 million cells, resuspend cell pellet in $80 \mu \mathrm{L}$ MACS buffer for every 10 million cells.

$8^{\circ} 4^{\circ} \mathrm{C}$ Wet Ice

$6 \quad$ Add $20 \mu \mathrm{L}$ CD45 microbeads per $80 \mu \mathrm{L}$ MACS buffer.

$8^{\circ} 4{ }^{\circ} \mathrm{C}$ Wet Ice

7 Incubate on ice or in $4^{\circ} \mathrm{C}$ refrigerator for 15 minutes.

00:15:00 Labeling

$8^{\circ} 4^{\circ} \mathrm{C}$ Wet lce 
8 During the incubation, prime an LS column: attach column to a MidiMACS separator and rinse the column with $3 \mathrm{~mL}$ MACS buffer.

9 Following incubation, resuspend cell/bead suspension with $900 \mu \mathrm{L}$ cold MACS buffer per $100 \mu \mathrm{L}$ suspension.

$8^{\circ} 4{ }^{\circ} \mathrm{C}$ Wet Ice

10 Spin suspension at $500 \mathrm{~g}$ for 4 minutes in $4^{\circ} \mathrm{C}$ pre-cooled centrifuge.

\section{(3) 00:04:00 Centrifugation}

$8^{\circ} 4{ }^{\circ} \mathrm{C}$ Centrifuge

11 Remove supernatant as completely as possible without disrupting cell pellet.

$8^{\circ} 4^{\circ} \mathrm{C}$ Wet Ice

12 Resuspend cell pellet in 500 uL cold MACS buffer.

$8^{\circ} 4{ }^{\circ} \mathrm{C}$ Wet Ice

\section{Magnetic Separation}

13 Transfer suspension to the primed LS column on the MidiMACS separator and collect the effluent (CD45 negative fraction) in $15 \mathrm{~mL}$ conical tube.

\section{$8^{\circ}$ Room temperature}

